\title{
ANÁLISE DA RESPONSABILIDADE POLÍTICA NO SISTEMA DE CRIMES DE RESPONSABILIDADE DO DIREITO BRASILEIRO CONTEMPORÊNEO
}

\footnotetext{
${ }^{1}$ Doutor em Direito e Ciência Política pela Universidade de Barcelona. Docente, Coordenador do Núcleo de Assistência Judiciária Gratuita - NAJ e membro do Conselho Universitário - CONUN, da Universidade do Estado de Minas Gerais - UEMG, Unidade Frutal. Ex-assessor de juiz do Tribunal de Justiça do Estado de Minas Gerais (2005-2013). Pesquisador registrado do CNPQ, Líder do Grupo de Pesquisa INOVA-EDUCA - Inovação na Educação para prevenção de delitos praticados pela juventude, na Universidade do Estado de Minas Gerais. Pesquisador registrado no CNPQ nos seguintes grupos de pesquisa: Laboratório Americano de Estudos Constitucionais Comparados - LAECC na Universidade Federal de Uberlândia (UFU); Núcleo de Estudos em Gestão e Impactos Ambientais (NEGIA), na Universidade do Estado de Minas Gerais. Texto produzido como desdobramento de projeto de pesquisa com fomento PAPq UEMG, com orientação de bolsista de iniciação científica. Currículo Lattes: http://lattes.cnpq.br/5314804984221674. Contato: moacir.junior@uemg.br.

${ }^{2}$ Graduanda em Direito pela Universidade do Estado de Minas Gerais, UEMG, da Unidade Frutal-MG. Bolsista de iniciação científica com fomento PAPq UEMG. Currículo Lattes: http://lattes.cnpq.br/0558464952500902. Contato: anna.monteiiro@gmail.com.
} 


\title{
RESUMO
}

Este trabalho pretende analisar as formas e o conteúdo da responsabilização política de agentes políticos no sistema constitucional brasileiro. A análise é centrada no sistema brasileiro de crimes de responsabilidade, com fundamentos na constituição federal e leis ordinárias. $\mathrm{O}$ objetivo geral é estudar as formas e o conteúdo da responsabilização política de agentes políticos no sistema constitucional brasileiro de crimes de responsabilidade. Já os objetivos específicos são analisar a natureza da responsabilidade política no Estado de Direito, o sistema de responsabilidade política no ordenamento constitucional brasileiro e o sistema de crimes de responsabilidade como forma de responsabilidade política no ordenamento brasileiro. A relevância científica se encontra na difusão do conhecimento sobre o tema, pouco difundido, todavia, tão complexo, utilizando para tanto não só o ordenamento jurídico brasileiro, mas também o direito comparado.

Palavras-chave: Responsabilização Política. Agente Político. Sistema Constitucional.

\begin{abstract}
This paper aims to analyze the forms and content of political accountability of political agents in the Brazilian constitutional system. The analysis is centered on the Brazilian system of crimes of responsibility, based on the federal constitution and ordinary laws. The general objective is to study the forms and content of political accountability of political agents in the Brazilian constitutional system of crimes of responsibility. The specific objectives are to analyze the nature of political responsibility in the rule of law, the system of political responsibility in the Brazilian constitutional system and the system of crimes of responsibility as a form of political responsibility in the Brazilian system. Scientific relevance is found in the dissemination of knowledge on the subject, which is not widespread, however, so complex, using not only the Brazilian legal system, but also comparative law.
\end{abstract}

Keywords: Political Accountability. Political Agent. Constitutional system.

\section{INTRODUÇÃO}

O presente artigo tem como escopo demonstrar a premente necessidade de garantir ao cidadão uma maior efetividade dos direitos sociais através das políticas públicas ligadas à seguridade social. A realidade brasileira é marcada por agudas desigualdades sociais, grande parte da população enfrenta dificuldades para obter uma condição de vida digna.

A responsabilidade política advém da obrigação de resposta, característica ofertada pelo sistema republicano presidencialista, o qual o Brasil adotou como modelo de governo, que tem como principal característica o sufrágio universal. Sendo assim, quando o povo exerce sua função de eleitor, ele escolhe um governante para representa-lo, devendo este, honrar com suas propostas e promessas. Quando eles não cumprem suas funções ou desviam dos atos íntegros como representantes, cabe a responsabilização, muito conhecida no país como "processo de impeachment". 
O impeachment é um instituto jurídico de grande importância político-social, mas, que após a queda do presidente Fernando Collor de Mello, acabou sendo esquecido não só pela população como também pelos cientistas jurídicos. Isso se deve a estabilidade do governo que não tem seus governantes retirados constantemente do poder. $\mathrm{O}$ autor complementa que esse fato fez que a produção de textos dogmáticos fosse reduzida, diminuindo o material para reflexão deste tema tão complexo que vem acordando novamente e fazendo com que a estrutura jurídica do impeachment seja incompreendida, bem como resultando dúvidas sobre a sua natureza política ou jurídica (SALVADOR NETTO, 2016).

O presente artigo trata justamente das formas de responsabilização, presentes tanto na Carta Magna quanto em leis especiais, principalmente a Lei de $\mathrm{n}^{\mathrm{o}} 1.079$ de 1950, os quais abarcam o tema dos crimes de responsabilidade, que apresentam os desvios de conduta dos agentes políticos, estudando assim, a natureza dos crimes de responsabilidade, a maneira que a mesma vem discriminada no sistema brasileiro de responsabilização, de que forma se inicia o processo de responsabilização e seus trâmites legais, bem como a quem é acometido e, por fim, as sanções.

A dúvida do presente trabalho nos levou a dividi-lo em três capítulos: o primeiro é justamente quanto às teorias de responsabilização e como ela se difundiu ao longo tempo e espaço, e em modelos democráticos diferentes, para entender conceitos. No segundo, questionamos as finalidades do processo. Será que a legislação realmente atende o que a teoria entende como responsabilização de agentes políticos? Para tanto, analisou-se a forma que a mesma se dá em meio a sociedade brasileira, isso porque a política no Brasil passa por uma enorme crise de representatividade, e, portanto, os indivíduos sentem a necessidade de estar cada vez mais afastados do campo político.

Ao fim, foi realizado estudo do caso da ex-Presidente da República, Dilma Vana Rousseff, a qual sofrera impeachment no ano de 2016, para suscitar questionamentos acerca das formas de responsabilização no sistema de crimes de responsabilidade, suas sanções e quanto das mesmas traduzem, de fato e de direito, o bem geral da nação, bem como se acontecem pelos mecanismos mais democráticas possíveis, em honra a soberania popular. Sendo assim, a relevância do trabalho resta na produção de análise da responsabilidade em diferentes contextos: na lei, na sociedade e na prática. 


\section{AGENTES POLÍTICOS E RESPONSABILIDADE POLÍTICA: CARACTERÍSTICAS DO ESTADO DE DIREITO REPÚBLICANO-DEMOCRÁTICO}

Para entendermos melhor sobre o tema ao qual abarcaremos neste trabalho, é importante que se entenda conceitos básicos, como o da responsabilidade política e dos agentes politicos.

Ao que tange semântica, responsabilidade vem da obrigação de responder pelos próprios atos e ações, ou até mesmo, por aquelas realizadas por outras pessoas, tendo assim o caráter de ser alguém que honra com seus compromissos. Em mesma análise, política remete a governar, organizar, dirigir e administrar nações ou países, guiando e influenciando o governo, opinião pública, relacionando-se nas esferas diversas para obtenção daquilo que se deseja atingir de forma política. Sendo assim, a responsabilidade política se vê intimamente atrelada ao compromisso ou obrigação entre governantes e governados, principalmente em relação as promessas feitas no exercício de sua função.

A responsabilidade apenas surge quando a igualdade estabelecese, isso porque antes de adotar o regime republicano-democrático, onde os governantes só chegam ao poder por outorga dos governados, havia a ideia de que o indivíduo detentor do governo não devia prestas contas aos súditos daquilo que ele prometeu, ou mesmo de suas ações, isso porque os mesmos não eram enxergados como seres semelhantes, havia hierarquia, principalmente quando falamos de monarcas e imperadores, vistos acima de seu povo, hierarquicamente superiores.

\footnotetext{
Durante muitos anos, vigorou no mundo ocidental uma noção de irresponsabilidade daquele que exerce o cargo de chefia do Poder Executivo, visto que a figura do monarca muitas das vezes confundia-se com a do próprio Estado. Havia o que se denominava de um — sistema de irresponsabilidadell, pois como o próprio nome indica, o rei não era responsabilizado por seus atos. (BIGNARDI, 2018)
}

Hobbes e Maquiavel, responsáveis respectivamente pelas obras "O Leviatã" e "O Príncipe", são clássicos para enxergar tal desigualdade. $\mathrm{O}$ primeiro, Hobbes, defende que ao dar à uma terceira pessoa a qualidade de "detentora do poder de decisão", a mesma possui autoridade ilimitada, não devendo responder aos governados, pois são investidos de majestade e sacralidade, sendo assim, o mero vínculo entre governantes e governados não implicava em responsabilidade, porque um superior não responde. 
[...] a responsabilidade depende de certas condições ambientais institucionais e sociais para que ocorra. A responsabilidade política existe na democracia e com sistemas representativos. O 'soberano' de Hobbes e de Carl Schmitt não responde politicamente aos súditos pois a sacralidade da investidura não importa em sinalagma com o súdito. Importa em majestade e não em responsabilidade. $\mathrm{O}$ sentido de representação de Hobbes está distante da ideia de obrigações sinalagmáticas entre o governante e o governado. [...] A teologia da política é que dita a assunção do governante e este não presta, este não responde ao governado (BORGES E CORREA, 2016)

Neste primeiro momento, o monarca e sua corte praticavam atividades sem nenhuma espécie de limitação, agindo de imperativo absoluto, sendo que mesmo que houvesse ou mais altos graus de injustiça e desigualdade, tratando de maneira não isonômica seu povo, de maneira que nada podia ser exigido do monarca no poder, isso porque encontravase em épocas de tirania, não havendo modelos de responsabilização pelo que era praticado pelo Estado.

Os agentes políticos exercem funções públicas, que podem consistir tanto na prática de atos políticos, quanto na prática de simples atos administrativos. [...] Em sistemas outros, como a monarquia, conforme já ocorreu no Brasil quando vigente a Constituição do Império, de 1824, pode-se adotar a regra de que o rei não erra, de que o rei é irresponsável. (DALLARI, 2000)

Já Maquiavel, traz que a responsabilidade de qual trata é em relação aos valores morais do príncipe mediante a condução do seu reinado para atingir os fins aos quais o posto de governante demanda, dando início a bilateralidade na relação, não sendo, ainda, claro a maneira como responderia aos seus governados, sabe-se apenas que ser o príncipe demandaria dedicação, sendo que governaria para o bem do seu povo, mesmo que seja um conceito subjetivo, impregnado de tracejo moral.

É no sentido pactistas e contratualistas, século XVII, que surge a responsabilidade, mais especificamente com os vínculos privados obrigacionais, sendo que John Locke traz o laço de confiança no sistema de representação, ao qual insere-se o governante, rompendo a sacralidade de Maquiavel e Hobbes, haja visto que defende que ninguém deveria ser privado da condição de liberdade, colocado sob domínio de um governante sem seu consentimento, colocando o poder supremo de decisão na mão do povo, limitando assim o poder daquele que está no comando do governo, sendo o poder legislativo o considerado supremo, devendo todos os demais derivarem dele ou subordinar-se ao mesmo. 
O poder executivo quando não estiver depositado numa pessoa que também participe do legislativo, estará visivelmente subordinado a este e a ele responde, podendo ser trocado e deslocado à vontade; [...] (LOCKE, 1998)

Da mesma forma, posiciona-se Efren Fernandez Pousa Junior, o qual afirma:

[...] que poder não é a coisa que serve para alcançar certo objetivo, mas a capacidade do sujeito em obter certos efeitos (o poder que o soberano tem de fazer as leis e, fazendo as leis, de influir sobre a conduta de seus súditos). Surge, pois, a idéia de um direito subjetivo em que o ordenamento jurídico atribui tanto aos governados, como aos governantes, o poder de buscar certos direitos nesta seara.

Também aqui, cremos, de forma mais evoluída, surgir a possibilidade de se vislumbrar um certo controle de atos, no sentido de limitar as formas corruptas de regimento político, onde o governante, tirano, não poderia mais governar apenas em seu próprio benefício, pelo menos a princípio, sem responder por seus atos perante os governados. Ao caracterizarem-se os direitos subjetivos despontam, pois, condições para apuração de responsabilidades, vez que o ordenamento jurídico atribui, ainda que de forma restrita, uma fração de poder aos governados, capacitando-lhes a obterem certos efeitos na relação social de poder, vez que agindo tais quais sujeitos de direitos. (POUSA JÚNIOR, 2012)

Sendo assim, fica nítido que a responsabilidade política está intimamente ligada ao poder político e as limitações da lei, em si (isso em decorrência do cargo, sua posse e ocupação, com limites definidos pela legislação). O conceito de poder e responsabilização devem ser fundidos, isso porque, sem o controle exercido entre as duas, como uma espécie de troca de freios e pesos, ocorre o fenômeno do excesso de poder, e deixa de ser saudável, passando a ser uma forma de controle, e não de governo.

É neste sentido que Montesquieu se posiciona sobre a liberdade do cidadão. Segundo o filósofo, é insuficiente que apenas haja positivação em texto constitucional, ela deve ser demonstrada nas relações com o povo, isso porque é na lei que o cidadão encontra as extensões e limites de sua liberdade, podendo, portanto, realizar tudo aquilo que a mesma não proíbe, haja vista que a igualdade de fato e de direito, seria aquela que oferece a segurança de que todos os cidadãos são proíbidos na mesma medida. Para Montesquieu, resta no Sistema de Freios e Contrapesos a medida da Constituição que oferta equilíbrio entre poder e liberdade, sendo que por 
meio dela que de resguarda o cidadão no âmbito do abuso de poder de seus governantes.

\begin{abstract}
A Liberdade política só se encontra nos governos moderados. Mas ela nem sempre existe nos Estados moderados; só existe quando não se abusa do poder, mas trata-se de uma experiência eternal que todo homem que possui poder é levado a dele abusar; ele vai até onde encontra limites. [...] Para que não se possa abusar do poder, é preciso que, pela disposição das coisas, o poder limite o poder. Uma constituição pode ser tal que ninguém seja obrigado a fazer as coisas a que a lei não obriga e a não fazer aquelas que a lei permite. [...] A liberdade política, em um cidadão, é esta tranquiidade de espírito que provém da opinião que cada um tem sobre a sua segurança; e para que se tenha esta Liberdade é preciso que o governo seja tal que um cidadão não possa temer outro cidadão. (MONTESQUIEU, 2000)
\end{abstract}

Legislar a respeito disso surge em um momento em que pautarse apenas na ética, nos bons costumes e na boa vontade do respeito já não era a maneira mais eficaz de equilibrar o poder. Sendo assim, é por meios legais e éticos que seria contextualizado assim a busca pelo controle (modulando a ética de ações praticadas pelos governantes) e a responsabilização (com base no texto constitucional, e nas normas especiais, afastar os distúrbios praticados no exercício do poder).

A responsabilização nada mais é do que uma nova forma de redução/limitação do poder: uma forma de fazer com que o chefe do Executivo guie-se pelos caminhos do interesse público, em detrimento de seu próprio interesse privado. (BIGNARDI, 2018)

É importante falar de igualdade pelo simples fato de que a república é baseada no seguinte princípio, bem como foi a mesma quem deu aos governados a licença para escolher quem iria governá-los, isso por meio do voto popular, e portanto, estabeleceu que não haveria hierarquia. O governante não é mais importante do que o povo, nem deve ser tratado de força diversa por conta do cargo que ocupa. Sendo assim, quando o agente politico usar de força irregular de suas atribuições, o mesmo poderá ser responsabilizado.

Como bem aduz Adilson Abreu Dallari:

É elementar, no sistema republicano, a possibilidade de se responsabilizar todo e qualquer governante. Esta consideração preliminar é feita para afastar entendimento equivocado no sentido de que a punição de um agente político configuraria agressão ao sistema constitucional. Ora, agressão ao sistema é não usar a 
possibilidade de responsabilização de todo e qualquer governante. Agredir o sistema é não aplicar esse mesmo sistema em toda a sua inteireza. (DALLARI, 2000)

Destarte, ao que se depreende é que a função da igualdade é, portanto, controlar o poder que é dado para o governante, ofertando à sua contraparte, o cidadão com plenos direitos politicos, a oportunidade de denunciar àqueles que não agem conforme o acordado, com seu dever. Segundo Celso Antônio Bandeira de Mello, detentor da corrente majoritária e de conceito fechado:

\begin{abstract}
Agentes políticos são os titulares dos cargos estruturais à organização política do País, ou seja, ocupantes dos que integram o arcabouço constitucional do Estado, o esquema fundamental do Poder. Daí que se constituem nos formadores da vontade superior do Estado. São agentes políticos apenas o Presidente da República, os Governadores, Prefeitos e respectivos vices, os auxiliares imediatos dos Chefes de Executivo, isto é, Ministros e Secretários das diversas Pastas, bem como os Senadores, Deputados federais e estaduais e os Vereadores. (DE MELLO, 2013, pg. 251-252)
\end{abstract}

\title{
Complementando a ideia de Bandeira de Mello, temos Mari Sylvia Zanella Di Pietro:
}

A ideia de agente político liga-se, indissociavelmente, à de governo e à de função política, a primeira dando ideia de órgão (aspecto subjetivo) e, a segunda, de atividade (aspecto objetivo). [...] São, portanto, agentes políticos, no direito brasileiro, porque exercem típicas atividades de governo e exercem mandato, para o qual são eleitos, apenas os Chefes dos Poderes Executivos federal, estadual e municipal, os Ministros e Secretários de Estado, além de Senadores, Deputados e Vereadores. A forma de investidura é a eleição, salvo para Ministros e Secretários, que são de livre escolha do Chefe do Executivo e providos em cargos públicos, mediante nomeação. É necessário reconhecer, contudo, que atualmente há uma tendência a considerar os membros da Magistratura e do Ministério Público como agentes políticos. (DI PIETRO, 2017)

Perante a Constituição Federal de 1988, os agentes políticos são, bem como os servidores públicos, militares e particulares que prestam serviço ao Poder Público, uma categoria de agentes públicos (pessoas naturais que exercem sua função à Administração Direta e ao Estado), sendo instituida pelo artigo 37 da Carta Magna. Estes exercem funções públicas, que podem traduzir-se tanto em atos administrativos quanto politicos, sendo que em quaisquer de suas atitudes, deverão ser responsabilizados, sendo parte do regime adotado, como já explanado. 
Importante destacar que a responsabilidade política é um tipo de responsabilização que atinge apenas os agentes politicos, sendo que acumula as responsabilizações referentes aos agentes públicos, entretanto, a contra-mão não funciona, sendo que a responsabilidade pelos atos tipificados como infrações politico-administrativas não se estende à todo agente público, sendo exclusive aos politicos. Sendo assim, o julgamento politico dos chamados crimes de responsabilidade, não obsta a responsabilização nas esferas penal, administrativa, cívil, popular ou mesmo dos atos de improbidade administrativa e fiscal.

Quando surgiram, na Inglaterra no século XIII, a ideia de crimes de responsabilidade adentrava na responsabilização penal das altas autoridades do poder público, no caso inglês, ante ao Parlamento, em observância ao modelo de governo seguido pelo país, fazendo-se ante a maioria parlamentar que o apoia. Os ingleses, dentre os países que trataram do assunto, são os que se destacam na análise e desenvolvimento do tema, sendo que inicialmente seus agentes responsabilizados respondiam tanto na esfera política quanto na criminal, tendo posteriormente dissociado os dois, focando-se em responder pelo cargo, tendo tipificação discricionária, não havendo imputação de determinada ação criminal descrita, podendo a denúncia vir por mera desconfiança do Parlamento ao chefe de governo.

Já nos Estados Unidos, onde o governo é presidencial, a responsabilidade faz-se ante aos cidadãos eleitores, com formulação híbrida, associando o politico e penal, ou seja, um modelo em que, para que o chefe de Estado e de Governo seja responsabilizado, este tenha que cometer determinadas tipificações legais, uma vez que um sistema peculiar penalista induz à tipicidade, que exige incidir em determinado conduta em norma criminal para que, por serem altamente reprovada socialmente, sejam sancionadas de forma devida, que também deve estar descrita em texto legal.

É unanimidade à ambos os sistemas de governo, o da sanção aplicável aos crimes de responsabilidade, perda do cargo. Entretanto, a forma de ingresso de representação é diferente, restando no povo para o presidencialismo, devendo ser eleitor, por meio de petição indicando quais os tipos penais que incidiu, bem como os elementos probatórios, cabendo ao Legislativo o julgamento do mérito. Já no parlamentarismo, é comum que ocorra tudo na centralidade do Legislativo, cabendo responder aos partidos e suas bancadas. 
A responsabilização política do executivo brasileiro pautou-se no Sistema Presidencialista-Republicano e surgiu apenas depois de muito tempo, tendo sido incluida no bojo jurídico brasileiro já na Constituição Federal de 1946, sendo remetida a legislação ordinária de lei própria que a regulava (Lei $\mathrm{n}^{\circ}$ 1.079, de 10 de abril de 1950, que define os crimes de responsabilidade e regula o respectivo processo de julgamento), ocorrendo com a imputação de conduta delituosa para configuração de crime de responsabilidade. Para tal julgamento de responsabilidade é que é instaurado o processo de Impeachment, para avaliar a gravidade do ato litigioso politico dos agentes politicos.

\section{O INSTITUTO DO IMPEACHMENT E A CRÍTICA DE AFASTAMENTO DA SOCIEDADE CONTEMPORÂNEA AO SISTEMA BRASILEIRO LEGAL DE CRIMES DE RESPONSABILIDADE}

Até o presente momento, foi possível compreender que a responsabilidade política é uma forma de equilíbrio de poder, onde é dado aos governados a possibilidade de recorrer de atos políticos de seus governantes, podendo assim cobrar uma resposta de governos decepcionantes, ou de atos considerados como gravosos perante o cargo elevado que possuem na administração do país. Como bem demonstram em sua fala, José Antônio Cheibub e Adam Przeworski, em "Democracia, eleições e responsabilidade política":

Governos são responsáveis na medida em que os cidadãos podem discernir se os governantes estão agindo de acordo com os seus interesses e sancioná-los apropriadamente, de forma que os governantes que satisfazem os cidadãos permanecem em seus postos e aqueles que não os satisfazem perdem suas posições. A responsabilidade política é um mecanismo retrospectivo, no sentido de que as ações dos governantes são julgadas a posteriori, em termos dos efeitos que causam. (CHEIBUB E PRZEWORSKI, 1997).

O processo de responsabilização de agentes é o que entendemos por procedimento de impeachment. Advindo do latim, "impedimentum", que significava impeder o ingress, na etimologia, seria proibir a entrada. Em origem inglesa, o verbo "to impeach", tem o sentido de denunciar pelo exercício ruim de atividade ou função, e, por meio deste, impedir que o 
indivíduo mantenha as condutas exercidas. Tal como fundamenta Sérgio Resende de Barros:

Tradicionalmente, como indica o seu próprio nome em inglês, o impeachment sempre teve por finalidade impeder o mau exercício de um cargo ou função, sobretudo de natureza política, com vistas a salvaguardar o Estado contra a ruína do seu governo e a deterioração da sua govrnabilidade. (BARROS, 2010)

Ainda, segundo o autor, hoje em dia o processo é procedimento de natureza política, que é instaurado, processado e julgado por parlamentares, contra agentes politicos de alto nível por condutas de alta reprovação moral e ética, impedindo que o mesmo continue exercendo sua função, bem como os atos de alta gravidade. Desde a Constituição de 1891, existe rol de crimes de responsabilidade, e o remetimento a lei especial. Desde então, é possível depreender, segundo Fábio Medina Osório:

Das Constituições republicanas brasileiras se podem recolher pelo menos três grandes conseqüências em relação ao tratamento dos delitos de responsabilidade: (i) o ilícito é, sobretudo a partir da Constituição de 1946, sempre uma violação da Constituição, sendo esta sua essência histórica; (ii) a conduta é politicamente inadequada ou indesejável, outro ponto rastreável no percurso histórico; (iii) é necessária a previsão legal para sua configuração enquanto ilícito, exigência que tem se assentado e consolidado com a solidificação dos Estados de Direito, contexto no qual o Brasil se insere. (OSÓRIO, 2007)

É possível constatar que o instituto existe a muito tempo, sempre descrevendo na Carta Magna os principais tipos penais, e posteriormente remetendo à lei específica que tratasse sobre tipificação, penas e trâmites do processo de responsabilização. Na atual Constituição Federal, qual seja a de 1988, o instituto pode ser encontrado no artigo 85:

Art. 85. São crimes de responsabilidade os atos do Presidente da República que atentem contra a Constituição Federal e, especialmente, contra:

I - a existência da União;

II - o livre exercício do Poder Legislativo, do Poder Judiciário, do

Ministério Público e dos Poderes constitucionais das unidades da Federação;

III - o exercício dos direitos politicos, individuais e sociais;

IV - a segurança interna do País;

V - a probidade na administração;

VI - a lei orçamentária;

VII - o cumprimento das leis e das decisões judiciais. 
Parágrafo único. Esses crimes serão definidos em lei especial, que estabelecerá as normas de processo e julgamento.

Ainda, segundo Súmula Vinculante 46, a competência legislativa é privativa da União para o estabelecimento das respectivas normas de processo e julgamento, e da definição dos crimes de responsabilidade, as quais se referem o parágrafo único do artigo 85 da Constituição Federal de 1988. Como pode se verificar com o texto constitucional, em todos os momentos se definem como "crimes" de responsabilidade, haja vista as origens penalistas do instituto no Brasil. Entretanto, erroneo a adoção do termo, haja vista que as figuras são tipicamente políticas, com julgamento e sanções políticas. Como mesmo pontua José Frederico Marques:

[...] crime de responsabilidade tem, no Direito brasileiro, um sentido equívoco, pois que não designa apenas figuras delituosas de ilícito penal, mas também violações de deveres funcionais não sancionadas com pena criminal. [...] delicta in officio, crimes de função, delicta propria dos que exercem funções públicas. No Direito Constitucional pátrio, o crime de responsabilidade opõe-se ao crime comum e significa 'a violação de um dever do cargo, de um dever de função', como dizia José Higino. Mas o sanctio juris contra essa infração não consiste em pena criminal, pois que seu julgamento e os efeitos jurídicos deste advindos são de outra espécie e moldam-se pela forma do instituto do impeachment. Como diz João Mendes Júnior, adotou o nosso legislador 'o instituto do impeachment, tal como figura na Constituição dos Estados Unidos da América do Norte, isto é, não podendo o Senado impor outras penas mais que a perda do cargo e a incapacidade e exercer qualquer outro, sem prejuízo da ação da justiça ordinária contra o condenado'. [...] Não nos parece que o crime de responsabilidade de que promana o impeachment possa ser conceituado como ilícito penal. Se a sanção que se contém na regra secundária pertinente ao crime de responsabilidade não tem natureza penal, mas tão só o caráter de sanctio juris política, tal crime se apresenta como ilícito politico e nada mais. (MARQUES, 2009)

Sendo assim, o caráter processual é politico, não tendo ligação com o formato tradicional penal, não se apurando nada além de responsabilidade pelos atos perante o povo, por ter sido eleito pelos mesmos para cuidar da Nação e da República, punindo-se a figura política, e não a personalíssima do agente politico, culminado em perda de cargo e de eventuais direitos politicos futuros. A respeito do processo, é importante deixar claro que são asseguradas as garantias principiológicas da legalidade, do contraditório e ampla defesa, do devido processo legal, e 
demais não mencionados, não podendo ser afastado da esfera política. A forma, em si, é de crime, entretanto, a substância é política.

\begin{abstract}
Segundo Gasparetto Júnior (2008), o procedimento do impeachment é divido em duas fases, sendo a primeira a preambular e denominada "juízo de admissibilidade do processo", executada na Câmara dos Deputados, tratando-se do processo propriamente dito, sendo que a segunda e última fase é executada pelo Senado Federal. De forma complementar, na fase inicial, a Câmara dos Deputados alegará procedente ou não a acusação, de forma a admitir o processo e julgamento pelo Senado Federal. (ABDALA, DOS SANTOS, GOMIDES, OLIVEIRA E RODRIGUES, 2018)
\end{abstract}

Como já pontuado, a responsabilidade dá-se perante o povo, portanto, é coesivo apontar que é permissivo a qualquer cidadão fazer a denuncia do agente politico perante a Câmara dos Deputados, isso porque, se responde aos eleitores, o cidadão, gozando plenamente de seus direitos politicos, é quem deve pedir contas dos atos. A denúncia deve ter fundamentação em prova, sendo que caso não a tenha o denunciante, este deve indicar local em que consigam obtê-las como elemento do processo, cabendo prova testemunhal, caso haja, na forma de mínimo de cinco pessoas.

Findada a fase de denúncia, a competência para o exame inicial, resta na Câmara dos Deputados, podendo a mesma ser rejeitada, caso seja inepta ou despida de justa causa, ou aceita.

Entende-se por juízo de admissibilidade, a competência dada à Câmara dos Deputados para, privativamente, autorizar, por dois terços de seus membros, a instauração de processo contra o Presidente e o Vice-Presidente da República e os Ministros de Estado. (RODRIGUES, 2016)

No presente caso, deverá ser organizada uma comissão especial para julgamento, devendo se reunir em 48 horas para eleger seu presidente, pessoa que deverá emitir parecer da denúncia ser ou não objeto de apreciação.

Art. 86. Admitida a acusação contra o Presidente da República, por dois terços da Câmara dos Deputados, será ele submetido a julgamento perante o Supremo Tribunal Federal, nas infrações penais comuns, ou perante o Senado Federal, nos crimes de responsabilidade. (CONSTITUIÇÃO FEDERAL, 1988) 
Esgotados debates acerca do parecer, o mesmo será votado nominalmente, e caso aprovado, pelo quorum anteriormente exposto, será instaurada a denúnicia, com eventual suspensão do exercício da função (art. 86, §1 $1^{\circ}$, II da Constituição Federal de 1988) e cortada à metade o subsídio do acusado até a sentença. É remetida ao Senado, onde é feito o julgamento, abrindo debates orais, e analisando o objeto da acusação.

No julgamento dos crimes de responsabilidade, "a opinião pública, os fatores emocionais ou puramente políticos podem ser levados em conta. [...] As provas e os indícios devem ser tidos em conta, no âmbito político, de forma muito peculiar, dependendo, sempre, da repercussão do caso nos meios de comunicação social e da legitimidade do exercício dos poderes punitivos" (OSÓRIO, 2016)

Com a obra "Mal-Estar ou fim dos amores politicos", Pierre Ansart afirma que as democracias incitaram no cidadão formas de abdicar dos espaços politicos os quais deviam ocupar, porém, em momentos de fervorozidade, há um despertar da frieza das democracias, aflorando inúmeras discussões em períodos eleitorais ou em momentos de instauração de processos administrativos ou politicos, como é o caso do impeachment. Destarte, é defendida a tese de que apenas há proximidade do eleitorado brasileiro à política nacional em dois momentos: primeiro o de obrigatoriedade participativa (eleições) e segundo, em momento de total descrença do cenário politico (atos reprováveis de chefes do executivo, que como consequência, geram o impeachment).

Sendo assim, a política, que deveria ser uma atividade dos cidadãos com plenos direitos politicos, um espaço ocupado com voto e discussões enriquecedoras, se torna um limbo de vacância, ocupado por incômodos a população, que ou se sente obrigada ou envergonhada de fazer parte. O politico toma para si o formato de algo oposto ao nobre e dotado de seriedade, o qual deveria investir-se, tangindo apenas ao que o torna negativo. Por conseguinte, é a crítica de Ansart trazer a cultura dos "malestares" criados pelas formas que a política foi pensada para a modernidade e como ela dá-se no mundo contemporâneo.

O que Ansart mostra é que o projeto institucional da modernidade tem o tagante de, ao invés de conduzir ao esclarecimento e às formas revolucionárias, direciona ao acomodamento, à distância displicente do mundo da política. O impacto da secularização e da institucionalização racional, o "desencantamento" do mundo, inclusive da política, não conduziu ao verismo, mas à contemporização e ao acomodatício. [...] Nessa ilustração, há o confront de dois cenários da política: o cenário da "descrença" da 
atualidade, que se realiza efetivamente e, de outro lado, o cenário da pretensão da política do projeto de modernidade, que não se realizou na forma original. (BORGES E CORREAA, 2016)

Posto isso, é importante entender que é deste cenário degradante, o qual a política se encontra inserida, que meios de comunicação, principalmente de mídia, se alimentam para conduzir a massa popular a se tornar um "espectador do circo político" ao invés de ser um participante de fato, o ofertando a incredulidade e o ceticismo. Quando se fala de política, há no imaginário popular a ideia de dúvida, de algo o qual não se discute, de pauta afastada do meio particular, quando o público veste o fardo de não ser algo que merece investimento de tempo ou merecedor de atenção.

Boaventura de Souza Santos alude em "Uma nova cultura política emancipatória" que existem duas formas de racionalismo na atualidade: o frio, que se traduz na consciência do eleitor de que existem obstáculos, e a quente, que é a força para superá-los. Segundo o autor, as duas correntes deveriam se complementar e não serem tratadas de maneira isolada, sendo ambas extremamente necessárias, pois a corrente fria é importante para que o povo se mantenha alerta e a quente para que não desistam da luta com facilidade. (SANTOS, 2006)

Consequentemente, por estar inserida no jogo político, a responsabilidade do agente político toma contornos parecidos, surgindo na sociedade como algo banal e reles, mesmo sendo instituto legal e normatizado (tanto na Constituição da República quanto em legislação especial), produzindo a afastabilidade de semelhante modo, por ser parte do que é considerado inconspícuo ao povo, e portanto, político. Segundo apresenta Sérgio Resende de Barros, acerca do impeachment, "a experiência histórica o revelara assim caricato e depreciado". Continua o raciocínio, Barros:

A doutrina brasileira tinha por ineficaz o instituto do impeachment. Para o fim de promover a responsabilidade presidencial, não enxergava nele "senão um tigre de palha". Não era "sequer um canhão de museu", [...] Era "apenas um monstro de pagoda... medonho na carranca e nas garras imóveis". Assim o caricaturou Rui Barbosa. [...] impeachment do Chefe da Nação, não passa de uma ameaça desprezada e praticamente inverificável". (BARROS, 2010)

Na visão de Sérgio Resende de Barros, a responsabilização política, traduzida pelo processo de impeachment, não passava de um instituto que existia na jurisdição, mas restava inaplicada, inefetiva, nos 
casos concretos. Sendo assim, se traduzia em um instituto que amedrontava, de certa forma, todavia no momento de efetiva contra resposta, nada se valia. Para além do povo, a política, como parte do sistema eleitoral, é instituto de competição, dotada de adversários, haja vista a forma pluripartidarista brasileira. Segundo Ansart, o instituto da responsabilização traz à democracia competitiva uma oportunidade de degradação do adversário, atingindo tanto os agentes politicos quanto seus respectivos partidos, deixando de lado o viés de respeito entre os opositores.

$\mathrm{Na}$ atualidade, a política é a técnica da procura do distanciamento e do estranhamento das pessoas às teses rivais; é a criação de desconfianças e suspeitas sobre as teses rivais; é a técnica dos escândalos, dos estereótipos, das conotações desvalorizantes. A política não é mais a técnica de construção de argumentos para demonstrar fraquezas do adversário, ou mesmo deixa de ser a apresentação de propostas, ou deixa de ser a pretensão de apresentação de propostas razoáveis. A política perde a natureza de convencimento e persuasão para se tornar o jogo de produção de desvios e descrenças, atacando as adesões afetivas existentes. A proeminência da mídia substitui os debates parlamentares (ou os debates tornam-se caudatários de exposições midiáticas). Pierre Ansart utiliza a expressão "máquinas de fazer descrer" para a compreensão deste fenômeno de decomposição, perda de respeito e de descrença. (BORGES E CORRÊA, 2016)

Principalmente pelo fato, já salientado neste, de que há enorme discussão acerca da responsabilidade política ser instituto meramente político, ou de maneira hibrida, se misturar com institutos criminais, que ocorre o que Pierre Ansart chama de "redução da estima, admiração e do respeito ao adversário", se traduzindo justamente do uso do instituto criminal para emitir, principalmente com o uso das mídias, haja vista a repercursão e o poder que as mesma possuem na modernidade, conceitos de valor e moralidade acerca de candidatos, fazendo com que os mesmo se tornem inelegíveis pela população, alimentando os esteriótipos do imaginário popular de incompetência, corrupção e repúdia ao campo da política. Como mesmo versava, Charles Montesquieu acerca dos ânimos populares:

Assim como a maioria dos cidadãos, que têm pretensão bastante para eleger, mas não para serem eleitos, o povo, que tem capacidade suficiente para fazer com que se prestem contas da gestão dos outros, não está capacitado para gerir. 
É preciso que os negócios funcionem, e que funcionem com um certo movimento que não seja nem muito lento, nem muito rápido. Mas o povo sempre tem ação ou de mais ou de menos. Algumas vezes com cem mil braços ele derruba tudo; outras vezes com cem mil pés, só caminha como os insetos. (MONTESQUIEU, 2000)

Voltamos assim a pauta da participação popular restar essencial para o processo de impeachment, sendo vital que se manifestem em relação às suas vontades, isso porque, caso não o faça, seus representantes parlamentares o farão sem considerar o clamor popular, restando na perda de uma chance de fazer-se ouvido.

[...] o termômetro do impeachment é a vox populi. Sem a voz do povo, o impeachment é um instituto mudo ou tartamudo. Ela o exige e o impulsiona e, até, em certos casos, o dispensa. [...] a representação reage na razão direta da pressão popular. [...] De fato, o impeachment não só nasceu, mas vive do clamor popular. Quando o povo o clama e reclama, o impeachment ganha vida. Quando não, é algo inerte, de que logo se esquece. Torna-se um banquete insípido, a que poucos comparecem. (BARROS, 2010)

Isto posto, contextualizando o que se depreende das falas de Pierre Ansart, Montesquieu e Sérgio R. Barros, conseguimos vislumbrar que, por deveras vezes, é a vontade reiterada do povo em retirar o governante do poder que faz com que as coisas aconteçam de fato e sejam levadas à frente, entretanto, nem sempre o povo está informado da maneira correta, visto que inúmeras vezes o que fomenta a pauta de responsabilização são preceitos midiáticos e não processos sérios de responsabilidade. Daí a deturpação do que é positivado em lei e a descrença da população em meios que já consideram falidos.

A responsabilidade pelos crimes políticos dá-se muito mais pelo encorajamento dos veículos de comunicação do que em decorrência do conhecimento do que trazem em seu bojo a Constituição e regulamentos específicos. O próprio entendimento da morosidade da justiça pública, ou da burocracia a qual é cometida, já geram a banalização do que é positivado em lei. A descrença na justiça, ou mesmo a vulgarização da política, vista sempre como veículo de mentiras e corrupção, faz com que a população se retire do seu espaço político.

Entretanto, se afastar do político é se afastar das demandas por elas provocadas, e com tal distanciamento, o abandono da legalidade é uma realidade próxima, e se torna cada vez mais ilusório alcançar o que é a responsabilidade política em si, deixando de ser o mecanismo de cobrança 
de eleitores para com seus governantes para se mostrar instituto intocável. Se torna um ciclo infinito: o povo, ignorante de seus direitos de cobrança, que banalizam a política e, portanto, não falam sobre ela, e, por conseguinte, continuam retirando suas informações sobre o assunto de veículos midiáticos, que consequentemente continuam falando sobre o tema, mesmo que de forma irresponsável, haja vista que a mesma funciona com o impulso da audiência, e por fim, investem o cidadão à posição de ouvinte e espectador, quando deveria ser atuante e participativo, e deste modo, continuam leigos em relação ao assunto. Como aduz Mario Sérgio Cortella:

Em relação à política, observamos uma atitude de desprezo, de asco ou nojo e ainda uma atitude de tédio. Considero que, na atualidade, predomina uma visão de desprezo ou de asco ou de tédio em relação à participação política, no sentido contrário ao de idiótes como autodefesa. [...] Existe um asco pela política, pois ela é associada à política partidária dos acordos espúrios e da corrupção, e existe um desprezo por se supor que política é uma coisa menor. O que me parece estranho é que em 2 mil anos, nós, no Ocidente, tenhamos transformado a concepção de política - que era o ápice da vida humana - de tal modo que hoje se entenda a vida política como safada e político como pilantra. Portanto, a mais nobre atividade da Antiguidade no Ocidente, da nossa mãe greco-romana, que era a política, passou a ser uma atividade considerada, agora, vergonhosa. [...] Do ponto de vista dos direitos do cidadão, da expansão da liberdade individual, do acesso à informação, tivemos uma mudança para melhor. Mas, no que se refere à percepção da importância da política, acho que tivemos uma mudança negativa, um movimento de desenobrecimento da atividade política, o que entendo como negativo do ponto de vista da sociedade. Isso me leva de volta à frase que já citei: "Os ausentes nunca têm razão". (CORTELLA, 2017)

Conclui-se então que, mesmo existindo, em texto constitucional e lei especial, a previsão da responsabilidade por crimes politicos, a mesma precisa da alavanca social para que funcione. Como os juízos da mesma continuam sendo usados para afastar cada vez mais os eleitores da atmosfera política, o instituto existe para nada mais além de jogos eleitorais e fomento de audiência para a mídia, sendo que, ao buscar legitimidade na vox populi, perde forma e força pelo afastamento e a descrença. A fervorosidade apenas em momento oportunos e a falta de informação acerca do assunto são sinais importantes da urgência de reestruturação, tanto social quanto legislativa. Como mesmo aduz Adilson Abreu Dallari:

Tudo quanto foi até agora exposto serviu para mostrar que não é por falta de normas jurídicas que a corrupção e a impunidade 
reinam soberanamente no Brasil. Todas as modalidades de responsabilidade existentes já se revelaram impotentes. Diferentes analistas já apontaram diferentes motivos para isso, com maior ou menor pertinência, podendo-se crer que, na verdade, haja uma somatória de concausas. (DALLARI, 2000)

Para além do julgamento popular, existe o julgamento de direito feito pelo legislativo brasileiro, como dito anteriormente, passado o juízo de admissibilidade feito pela Câmara dos Deputados, a demanda é submetida ao Plenário da Casa, leia-se Senado Federal, para a análise do mérito de crime de responsabilidade, sendo que quando forem identificados crimes comuns, a mesma será remetida ao Supremo Tribunal Federal. Portanto, a Câmara tem apenas o poder de autorizar a abertura do processo, enquanto o Senado faz, por maioria simples, o juízo de instalação do procedimento, também por maioria simples, sendo afastado o presidente, e o julgamento, com eventual condenação ou absolvição darse-á apenas por maioria qualifica e, caso gere condenação, cominará nas penas ditas na Lei 1079 de 1950, as quais passaremos a expor.

\section{4 \\ AS FORMAS DE RESPONSABILIZAÇÃO POLÍTICA NO SISTEMA BRASILEIRO E O CASO DE DILMA VANA ROUSSEFF}

Para além da denúncia e da acusação, com o julgamento, "findados debates orais e retiradas as partes, abrir-se-á discussão sobre o objeto da acusação" (art. 30 da Lei no 1.079\50), sendo que, encerrada a mesma, "o Presidente do Supremo Tribunal Federal fará relatório resumido da denúncia e das provas da acusação e da defesa e submeterá a votação nominal dos senadores o julgamento" (art. 31 da Lei $n^{\circ}$ 1.079\50). A Constituição Federal, em seu art. 52, que trata da competência do Senado Federal, na primeira parte do parágrafo único, trata que nos casos de processo e julgamento do Presidente da República, nos crimes de responsabilidade, funcionará como Presidente o do STF.

A partir disso, só há dois caminhos: à absolvição, produzindo todos os efeitos a favor do acusado de praxe, segundo art. 32 da Lei $n^{\circ}$ 1.079\50, ou a condenação, dando poderes ao senado para deliberar e ditar período em que o condenado estará inabilitado para exercer qualquer função no âmbito público, e caso haja eventual crime comum, deliberarão a possibilidade de leva-lo a justiça ordinária para responder independente 
de representação de interessado, mediante art. 33 da mesma lei, não esquecendo que, com a sentença condenatória, como dita o art. 34 do mesmo diploma legal, o acusado é destituido do cargo.

Note que no artigo, encontra-se à expressão ipso facto, do latim, que significa "pelo próprio fato", "como resultado da evidência do fato", "como consequência obrigatória do fato", ou seja, é consequência direta da condenação que o agente político responda com o cargo ou função, haja visto o caráter político do crime e do próprio julgamento.

A segunda parte do parágrafo único do art. 52, da Constituição Federal, também trata das penas no caso de eventual condenação do Presidente da República, por dois terços do Senado, e, portanto, 54 senadores, nos crimes de responsabilidade: haverá a "perda do cargo, com inabilitação, por oito anos, para o exercício de função pública, sem prejuízo das demais sanções judiciais cabíveis". Merecedor de atenção e destaque o fato de as penas de condenação do crime de responsabilidade não prejudicar em nada outras demais que possam ser aplicadas. Como já explanado, o crime de responsabilidade não obsta da responsabilização por crimes patrimoniais, penais, popular, de improbidade administrativa e fiscais.

De maneira sucinta, os ensinamento de Adilson Abreu Dallari no artigo "A responsabilidade do agente político" traduzem: a responsabilidade patrimonial, encontrada no artigo $37, \S 6^{\circ}$ da Constituição Federal, é aquela decorrente de conduta dolosa ou culposa do agente político em que tiver sido paga indenização, cabendo regressão contra o mesmo; a responsabilidade penal, prevista no Título Crimes Contra a Administração Pública, no Código Penal, e depende da prática de qualquer um dos verbetes criminais; a responsabilidade popular, decorrente do artigo $5^{\circ}$, LXXIII, da Constituição Federal e da Lei $n^{\circ}$ 4.717\65, decorre do dano ao patrimônio público e eventual condenação em Ação Popular. A responsabilidade por atos de improbidade administrativa tem viés Constitucional, no artigo $37, \S 4^{\circ}$ e na Lei $\mathrm{n}^{\circ} 8.429 \backslash 92$, prevendo penas de suspensão de direitos politicos, perda de cargo, indisponibilidade de bens e ressarcimento erário, cabendo ação penal. Já a responsabilidade fiscal é instituto novo, que propõe planejamento, controle e economicidade da gestão financeira de natureza pública, em todas suas esferas, impotando em crime de responsabilidade ou crime comum. (DALLARI, 2000)

Sendo assim, o agente político responde com o cargo e inabilitação para funções políticas, sendo assim, as penas não são de 
natureza criminal, e sim de cunho político. Como parte concreta da história do impeachment brasileiro, temos o caso Fernando Collor de Mello, de 1992, e o mais recente, de Dilma Vana Rousseff, em 2015. Para contextualizarmos todo o exposto ao longo do presente, é interessante trazer à baila o caso Rousseff, principalmente por ser o mais presente e atual, e portanto, mais recente em memória.

Eleita pelo Partido dos Trabalhadores (PT) pelo segundo mandato, Dilma Rousseff se manteve no campo político, entretanto, teve dificuldades para o exercício. O PT se mantinha no poder desde 2002, e à partir de então houve uma série de questionamentos para cassar chapas, projetos de lei para dificultar o cumprimento das metas fiscais, entre outros, impossibilitando e inviabilizando a governabilidade do executivo federal. Para além da perda de base parlamentar, há a evidente insatisfação da população em relação ao seu governo impopular.

A denúncia foi ofertada pelos juristas Hélio Bicudo e Miguel Reale Júnior e pela advogada Janaína Paschoal, no dia 21 de outubro de 2015, ao na época presidente da Câmara dos Deputados, Eduardo Cunha, por crime de responsabilidade. Segundo consta, o segundo mandato de Dilma for a alvo de cerca de trinta denúncias semelhantes. Importante ressaltar que Eduardo Cunha havia rompido alianças coligatórias com o partido dos trabalhadores poucos meses após conseguir o cargo de chefia na Câmara, o que fora fator decisivo para o aceite do processo, sendo que caso houvesse perdurado a aliança, seriam mínimas as chances de Rousseff ter sofrido o impeachment

Sobre a peça, Fábio Medina Osório:

Em apertada síntese, a denúncia derradeira trata, primeiramente, de conjunto de fatos que apontariam para a prática de crime de responsabilidade por atentado à probidade na administração, isto é:

1) das crises econômica, política e moral pelas quais passa o Brasil;

2) da reabertura do julgamento das contas da Presidente pelo Tribunal Superior Eleitoral, mais em específico por meio da Ação de Impugnação de Mandato Eletivo $\mathrm{n}^{\circ} 761$ (761.2015.6.00.000);

3) da Ação Penal Originária no 470 - caso "mensalão" -, julgada pelo Supremo Tribunal Federal - STF - ao longo dos anos de 2012 e 2013, por meio da qual "restaram expostos os planos de perpetuação no poder por parte do Partido Político ao qual a Presidente da República é filiada";

4) da corrupção envolvendo a Petrobras, apurada pela "Operação Lava Jato" e revelada com a compra da Refinaria de Pasadena, época em que a denunciada era Presidente do Conselho de Administração da Petrobras; 
5) de depoimentos prestados por Paulo Roberto Costa e Alberto Youssef, dando conta do esquema de corrupção envolvendo o desvio de verbas da Petrobras e do conhecimento e conivência da Presidente em relação aos ilícitos que vinham sendo praticados por agentes públicos em prejuízo da referida sociedade;

6) do Partido dos Trabalhadores e de Luís Inácio Lula da Silva, relacionando-os com as empreiteiras investigadas na "Operação Lava Jato" e afirmando-se que Lula nunca saiu do poder, sendo indissociável à Presidente Dilma Rousseff;

7) de remessas sigilosas de valores pelo Banco Nacional de Desenvolvimento Econômico e Social - BNDES - ao exterior do país, para a realização de obras por empreiteiras brasileiras envolvidas nos escândalos da Petrobras;

8) do envolvimento da ex-ministra Erenice Guerra em caso de corrupção investigado na "Operação Zelotes";

9) da relação suspeita de Dilma Rousseff com Graça Foster, Nestor Cerveró e Jorge Zelada, ao protegê-los contra as denúncias de envolvimento com corrupção na Petrobras; e

10) do fato da Presidente manter em cargos importantes pessoas sob suspeita, como Edinho Silva, Ministro de Comunicação Social, tesoureiro da campanha eleitoral da Presidente, apontado como receptor de quase $\mathrm{R} \$ 40.000 .000,00$ (quarenta milhões de reais). (OSÓRIO, 2016)

Entretanto, foi admitida em parte pela Câmara dos Deputados (DEN n.1/2016), tendo sido acusada apenas por ter utilizado de decretos para autorizar abertura de crédito sem respeitar a legislação brasileira, permitindo "a abertura de recursos suplementares quando já se sabia da inexequibilidade das metas de superávit estabelecidas por lei” (Brasil. Câmara dos Deputados, 2015). Basicamente, uma manobra conhecida popularmente como "pedalada fiscal" onde a ex-presidente teria realizado manobra fiscal com o Plano Safra, em detrimento do repasse em atraso referente ao Banco do Brasil e o Tesouro Nacional, bem como de ter autorizado os decretos relativos à orçamento sem expressamente autorizar o Congresso Nacional. Basicamente, foi acusada pelos decretos suplementares sem autorização e as pedaladas fiscais.

[...] foram assinados pela presidente decretos sem anuência do congresso nacional que liberaram vultuosas quantias de dinheiro ao governo federal e isso tudo sem o respeito a meta fiscal prevista no ano de 2014, situação essa que configura de plano o crime de responsabilidade fiscal, posto que viola a probidade da administração capitulada no diploma legal 85, V da constituição federal do Brasil. (SARAIVA, 2016)

Dito isso, é nítido que os crimes a qual denuncia-se a chefia do Estado e Governo, eram de ordem orçamentária, haja vista artigo 85, VI, 
CR $\mid 88$, e de guarda e o legal emprego dos dinheiros públicos, mediante inciso VII, do artigo 85, CR 188 ; bem como a edição de decretos que culminaram a abertura de créditos suplementares sem autorização legislative e indicação dos recursos correspondentes, proibido pelo artigo 167, V da Carta Magna. Passaram ao rito de mobilização de comissão especial, pela Câmara.

Em dezembro de 2015, foram montadas chapas para concorrer a comissão especial, entretanto, foi anulada pelo Supremo Tribunal Federal, isso porque uma das chapas não havia sido indicada pelos lideres partidários e a votação tinha sido secreta, já que o correto era ser aberta, ofertando transparência. Já em 2016, foi feita nova comissão, agora seguinto todos os critérios legais, tendo, em abril, oferecido parecer a favor da abertura do processo, por meio do relator Jovair Arantes, aprovados pelo voto de 38 deputados, tendo 27 votado contra a instauração, sendo que na sessão de abertura do inquérito, eram necessário 342 votos para que fosse aberto, tendo 367 deputados votado a favor, e portanto, passado neste juízo de admissibilidade, tendo se dirigido ao Senado.

Ao Senado é dada a competência para julgar o mérito da acusação, já admitida pela Câmara dos Deputados, tendo sido designado pelo Supremo Tribunal Federal, que o Senado discutisse, também, a abertura do inquérito, tendo sido aprovado por 15 votos, o parecer favorável a abertura do inquérito, oferecida pelo relator Antonio Anastasia, tendo sido aberto por 55 votos à 22 contrários. Neste estágio, a presidente Dilma Rousseff fora afastada de suas funções, mediante o art. $23, \S 5^{\circ}$, que diz que "são efeitos imediatos ao decreto da acusação do Presidente da República, ou de Ministro de Estado, a suspensão do exercício das funções do acusado e da metade do subsídio ou do vencimento, até sentença final”, ponto em que assumiu seu posto o vice-presidente Michel Temer.

Sobreveio, então, o parecer do Relator, com proposta de "emendatio libeli" para os fatos descritos na denúncia como realização de operações de crédito com instituição financeira controlada pela União (pedaladas fiscais) subsumindo-os ao disposto no art. 10, itens 6 e 7, da Lei $\mathrm{n}^{\circ}$ 1.079/50, mantida, no mais, a definição jurídica originalmente proposta para a imputação remanescente. Inobstante a apresentação de voto em separado da Senadora Vanessa Grazziotin e outros Senadores, tal relatório foi discutido e aprovado pela Comissão Especial, na data de 02 de agosto. Na sequência, em 09 de agosto, sob a presidência do Ministro Lewandowski, o Senado Federal, como órgão judiciário, em sessão plenária, aprovou o referido parecer e pronunciou a acusada pela prática, em tese, dos crimes de responsabilidade a ela imputados. (BARBOSA, 2016) 
Quanto ao julgamento, após ouvidos informantes e testemunhas, tanto da acusação quanto da defesa, passando para o interrogatório da presidente acusada, tendo, posteriormente, acontecido os debate orais e a discussão da matéria pelos 63 senadores e senadoras, chegando à votação, que for a dividida em dois blocos: o primeiro sobre o real cometimento de crime de responsabilidade pela presidente, e a segunda sobre a inabilitação para exercer cargo na esfera pública. A primeira votação a condenou a perda do cargo, isso porque, por 61 votos à 20, foi imputado a presidente os crimes de responsabilidade aduzidos (as pedaladas fiscais e os decretos inaltorizados). Entretanto, a segunda votação, a qual inabilitaria Rousseff do exercício público, não conseguiu atingir quorum de dois terços de votos, tendo 42 votos à favor, 36 contra e três abstenções.

Finda-se o processo de impeachment contra a Presidente da República do Brasil, a qual foi retirada do cargo de presidência, sendo assumido definitivamente por seu antes vice, Michel Temer, entretanto, não ficara inabilitada de exercer função pública pelo período de oito anos.

Conforme Resolução $n^{\circ} 35$, de 31 de agosto de 2016, do Senado Federal do Brasil, que dispôs sobre as sanções no Processo de Impeachment contra Dilma Vana Rousseff, foi julgada procedente a denúncia por crimes de responsabilidade previstos nos art. 85, inciso VI, e art. 167, inciso V, da Constituição Federal de 1988, art. 10 , itens 4,6 e 7 , e art. 11, itens 2 e 3 , da Lei ${ }^{\circ} 1.079$, de 10 de abril de 1950. Foi imposta à Dilma Rousseff a sanção de perda do cargo de Presidente da República. (BARBOSA, 2016)

É conclusivo, que, quanto a forma e o rito, o qual deu-se o processo de Dilma Rousseff, ex-Presidente da República, em tudo fora seguido quanto as instaurações, juízos e votações. Entretanto, quanto deste evento político representou resposta em relação aos governados, ou realmente foram de encontro com a vontade popular de fato, e não representaram um jogo da própria política e da mídia, como se posiciona Ansart? É possível entender que, desde a propositura, dada por jurístas e não meros cidadão comuns, a opinião pública só fora consultada por meio da mídia, leia-se pesquisas de meios de comunicação e headlines com números de manifestantes, as quais Pierre Ansart e Sérgio Resende Barros nos acometem com críticas de manipulação e distorção.

Mesmo que os deputados e senadores sejam cidadãos eleitos por outros, acometidos de poder indireto, como aduz o artigo primeiro, parágrafo único, da Constituição da República de 1988 -constante do que seria conhecido como contrato social, de Rousseau-, como Estado 
Democrático de Direito, o qual tem como fundamento que "todo o poder emana do povo", e que possuiu mecanismos efetivos de consulta popular positivados em seu bojo legislativo, poderiam ter adotado, como forma mais democrática, maneira direta de exercício do poder de escolha do povo.

Se havia modo de consulta direta, eficaz e democrática de consulta popular, utilizer-se da mídia, ou pautar-se apenas na decisão de parlamentares, seria cercear no povo o verdadeiro termômetro do impeachment, e portanto, calar a vox populi, a qual se refere Sérgio Barros. As informações, as quais os cidadãos possuem acesso, nem sempre são libertadoras, sendo que, segundo Ansart, muitas vezes surgem como instrumento para afastar as pessoas da política, por meio da incredulidade e do asco à tudo que tange o político, gerando fervorosidades em épocas eleitorais, ou como a de responsabilização política, fomentando a ideia de injustiça e ceticismo. Como, já citado, Montesquieu: "o povo sempre tem ação ou de mais ou de menos. Algumas vezes com cem mil braços ele derruba tudo; outras vezes com cem mil pés, só caminha como os insetos".

O que se discute não são os méritos de culpabilidade, ou mesmo os elementos probatórios usados para o julgamento, mas a respeito do resultado ter sido o mais satisfatório para a vontade geral. Rousseau, em "O contrato social":

\footnotetext{
Nunca se corrompe o povo, mas com freqüencia o enganam, e só então ele parece desejar o mal. Via de regra, há muita diferença entre a vontade de todos e a vontade geral; esta se refere somente ao interesse comum, enquanto a outra diz respeito ao interesse privado, nada mais sendo que uma soma das vontades particulares. Quando, porém, se retiram dessas mesmas vontades os mais e os menos que se destroem mutualmente, resta, como soma das diferenças, a vontade geral. (ROUSSEAU, 1999)
}

Ainda segundo o autor, se o povo tem informação o suficiente quanto ao assunto, e, portanto, faz suas escolhas de forma isolada, das pequenas diferenças surgiria algo em comum, considerada a vontade geral. Todavia, com o surgimento de localismos, associações ou facções, as decisões podiam até ser gerais, mas traduziriam a vontade geral de cada grupo, e não de um bem maior. Se considerada, as teses de Rousseau traduziriam que: I. como o povo, pelos próprios meios que se deram a política no Brasil, procuram estar cada vez menos inseridos no meio político, e por isso, são cada vez menos informados, estes não fariam escolhas boas e conexas; II. como a mídia, bem como os deputados e senadores, se traduzem em associações de pessoas com interesses 
particulares, e nos casos dos dois últimos, políticos, envolvidos, por conseguinte, esta não traduziria a vox populi, e sim a vontade de uma maioria, em um grupo isolado, III. levando em consideração as duas primeiras teses, por maneira indutiva, e utilizando as teses rousseanas, não houve soberania popular, ou a vontade geral, e sim, a vontade de todos (os participantes nos seus referents nichos), o que não seriam democráticos de fato, apenas de direito.

O povo, por si, quer sempre o bem, mas nem sempre o reconhece por si só. A vontade geral é sempre reta, mas o julgamento que a guia nem sempre é esclarecido. [...] Então das luzes públicas resulta a união do entendimento e da vontade no corpo social, daí o exato concurso das partes e, enfim, a maior força do todo. (ROUSSEAU, 1999)

\section{CONSIDERAÇÕES FINAIS}

Ao ser instaurado o sistema republicano-democrático no Brasil, estabeleceu-se que os governantes chegariam ao poder por meio do voto universal, que ofertava igualdade nas relações, não sendo mais santificada a figura dos chefes da nação, portanto, não mais hierarquicamente superiores, devendo assim responder pelos atos praticados na vigência de seus mandatos. Tal responsabilização é positivada tanto em texto constitucional, quanto em legislação especial, tendo previsão de quem é responsabilizado, os tipos de atos que são considerados ilícitos, o procedimento o qual é acometido o agente, bem como as sanções.

Muito embora haja tudo constante em lei, o afastamento da população do campo político em muito dificulta que haja disseminação de informação, e com isso, que os trâmites legais aconteçam da forma democrática direta. A esfera política do país se tornou inconspícua, digna de dúvida e ceticismo, ofertando extrema crise de representatividade. Sendo assim, seguindo a linha de raciocínio de filósofos como Montesquieu e Rousseau, bem como de Pierre Ansart, chegamos à conclusão de que o povo brasileiro age de forma impulsiva, em momentos de fervorozidade. Importante também identificar que, parte do afastamento, é provocado pela ausência de informação acerca do assunto, as quais costumam obter de veículos de informação que os transformas em espectadores de uma atividade a qual todos deveríamos ser protagonistas. 
Se há afastamento e desconfiança do campo político, porque um julgamento realizado por políticos seriam a forma mais democrática de tradução da vontade popular? Ao levarmos em consideração a vontade, segundo Rousseau, a conclusão é de que a responsabilidade acontece perante o povo, entretanto, nem sempre os cidadãos têm informação suficiente ou são representados de maneira correta, apresentando-se como a democracia da maioria, e não como vontade geral, não podendo ser considerada democrática, e sim, de cunho político.

Sendo assim, a responsabilidade política, ao invés de dar às pessoas a segurança e tranquilidade em relação aos seus governantes, haja vista que há mecanismos para retirar do poder quem não cumpre com seu papel, inclusive positivados na carta máxima do bojo jurídico brasileiro, na verdade o que ocorre, segundo o posicionamento de Ansart, é o contínuo aumento do asco pelos crimes, expandindo a descrença no que é político, distanciando cada vez mais o eleitor da política, e portanto, deixando os procedimentos cada vez menos democráticos. O Brasil encontra-se paralisado na corrente fria de Boaventura Souza Santos, isso porque o eleitor brasileiro tem facilidade em entender os defeitos presentes no meio político e em acreditar nos veículos de comunicação que banalizam mais ainda o assunto, entretanto, no momento de agir em relação aos problemas, o afastamento os impede de ser atuantes, corrente quente, não possuindo a força para mudar as coisas.

Portanto, o que sustentaria a responsabilidade política por crimes de responsabilidade no Brasil, é a falsa sensação de justiça quanto a responsabilização de um agente político, e que, muito do juízo formado pelos cidadãos se constituem de maneira preconceituosa, reiterada pela mídia e por grupos políticos com interesses para com a responsabilização e seus efeitos. A maneira como é conduzida, a responsabilização por meio do processo de impeachment, é sempre cordial para com os preceitos legislativo, entretanto, muitas vezes representa não a vox populi, ou o clamor popular, considerado por Barros como o "termômetro do impeachment", mas sim, a vontade de um grupo, em nome da vontade de todos, que nem por isso é confundida com a vontade geral, para o bem de todos.

\section{REFERÊNCIASBIBLIOGRÁFICAS}


ABDALA, Samira França; DE OLIVEIRA, DOS SANTOS, Keysiane Dias; Iara Moura; GOMIDES, Bianca Marques; RODRIGUES, Jhuly. O impeachment no ordenamento jurídico brasileiro. Jus Artigos. Postado em dez. 2018. Disponível em: 〈https://jus.com.br/artigos/70673/o-impeachmentno-ordenamento-juridico-brasileiro >. Acesso em: dez. 2018.

ANSART, Pierre. Mal-estar ou fim dos amores politicos. História e perspectiva, Uberlândia, 2001;2002, 55-80.

BARROS, Sérgio Resende. Estudo sobre o "impeachment". Postado em 2010. Disponível em: <http://www.srbarros.com.br/pt/estudo-sobre-o-impeachment.cont >. Acesso em outubro de 2016.

BARBOSA, Alex Trindade. O processo de impeachment de Dilma Rousseff e a Vontade Geral do brasileiro. ResearchGate, 2016. Disponível em:

< https://www.researchgate.net/publication/312377722_O processo de impeachment de Dilma Ro usseff_e_a Vontade_Geral_do_brasileiro>. Acesso em: out. 2018.

BIGNARDI, Adauto H. Estephanini. Impeachment, uma crítica a partir do caso concreto. Repositório UFU, Uberlândia. Disponível em:

<https://repositorio.ufu.br/bitstream/123456789/22239/1/ImpeachmeantCr\%C3\%ADticaCaso.pdf >. Acesso em: 20 set 2018.

BLUME, Bruno André. Impeachment de Dilma: uma retrospectiva. Politize!. Postado em 2016. Disponível em: <http://www.politize.com.br/impeachment-de-dilma-retrospectiva/>. Acesso em: set. 2018.

BORGES, Alexandre Walmott; CORRÊA, Andrey Lucas Macedo. A Responsabilidade Política: uma contextualização crítica a partir de Pierre Ansart. Revista Estudos Institucionais, Rio de Janeiro, v. 2, n. 1, p.333- 366, p. 337 e 338: 2016. Disponível em:

<https://www.estudosinstitucionais.com/REI/article/viewFile/29/53 >. Acesso em: out. 2018.

BRASIL. Lei no 1.079 de 10 de abril de 1950. Planalto Legislação, 1950. Disponível em: <http://www.planalto.gov.br/ccivil 03/LEIS/L1079.htm>. Acesso em: mai. 2018.

BRASIL. CONSTITUIÇÃO DE 1988. Constituição da República Federativa do Brasil de 1988. Planalto Legislação, 1988. Disponível em: <http://www.planalto.gov.br/ccivil_03/Constituicao/Constituicao.htm>. Acesso em: mai. 2018.

BRASIL. Supremo Tribunal Federal. A Constituição e o Supremo. Brasília. Disponível em: <http://www.stf.jus.br/portal/constituicao/artigobd.asp?item=\%20950>. Acesso em: dez. 2018.

CHEIBUB, José Antônio; PRZEWORSKI, Adam. Democracia, eleições e responsabilidade política. Revista Brasileira de Ciências Sociais. São Paulo. Postado em Fev. 1997. Disponível em: $<$ http://www.scielo.br/scielo.php?pid=S0102-69091997000300004\&script=sci_arttext $>$. Acesso em: 10 dez. 2018.

CORTELLA, Mario Sergio; JANINE RIBEIRO, Renato. Política para não ser idiota. Papirus e 7 Mares, 2017. Disponível em: <http://politicaedireito.org/br/wp-content/uploads/2017/02/Politica para-nao-ser-idiota-Mario-Sergio-Cortella.pdf >. Acesso em: nov. 2018. 
DALLARI, Adilson Abreu. A responsabilidade do agente político. Revista Jus Navigandi. Teresina. Postado em jun. 2000. Disponível em: 〈https://jus.com.br/artigos/354〉. Acesso em: 04 nov. 2018.

DI PIETRO, Maria Sylvia Zanella. Direito Administrativo. Rio de Janeiro: Forense, 2017.

MARQUES, José Frederico. Elementos de Direito Processual Penal. Campinas: Millennium, 2009.

MELLO, Celso Antônio Bandeira de. Curso de Direito Administrativo. São Paulo: Malheiros Editores, 2013.

MONTESQUIEU, Charles de Secondat, Baron de. O espírito das Leis. Apresentação de Renato Janine Ribeiro; tradução de Cristina Murachco. São Paulo: Martins Fontes, 1996.

OSÓRIO, Fábio Medina. Crimes de responsabilidade da Presidente da República. Postado em 2016. Disponível em: 〈https://www.migalhas.com.br/arquivos/2016/4/art20160411-07.pdf〉. Acesso em: nov. 2018.

PEREIRA NETO, Luiz Gonzaga. Os agentes políticos e sua responsabilização à luz da Lei $n^{\circ}$ 8.429/92. Jus Artigos. Postado em 2007. Disponível em: <https://jus.com.br/artigos/9588/osagentes-politicos-e-sua-responsabilizacao-a-luz-da-lei-n-8-429-92>. Acesso em: abr. 2018.

POUSA JUNIOR, Efren Fernandez. O Poder e a Responsabilidade. Conteúdo Jurídico, Brasilia. Postado em maio 2012. Disponível em:

<http://www.conteudojuridico.com.br/?artigos\&ver=2.37007\&seo=1 >. Acesso em: 30 ago. 2018.

RODRIGUES, Anna. Impeachment - o que dizem a Constituição Federal e o Supremo Tribunal Federal?. Gran Cursos Online. Brasília. Postado em abr. 2016. Disponível em: < https://blog.grancursosonline.com.br/impeachment-o-que-dizem-constituicao-federal-e-o-supremotribunal-federal/>. Acesso em: nov. 2018.

ROUSSEAU, Jean-Jaques. O contrato social. Tradução de Antônio de Pádua Danesi. Martins Fontes: São Paulo, 1999.

SALVADOR NETTO, Allamiro Veludo. Perspectivas dogmáticas do impeachment. Revista Brasileira da Advocacia, v. 0, jan./março de 2016. Disponível em: <http://www.revistadostribunais.com.br >. Acesso em: mai. 2016.

SANTOS, Boaventura de Souza. Una nueva cultura política emancipatoria. In: Boaventura de Souza Santos. Renovar la teoría crítica y reinventar la emancipación social: encuentros en Buenos Aires. Buenos Aires: Universidade de Buenos Aires, 2006.

SARAIVA, Rodrigo Pereira Costa. Uma análise jurídica sobre o processo de Impeachment da Presidente Dilma. Jus Artigos. Postado em: mai. 2016. Disponível em: <https://jus.com.br/artigos/49440/uma-analise-juridica-sobre-o-processo-de-impeachment-dapresidente-dilma>. Acesso em: dez. 2018. 